\title{
Organic compost as a conditioner of soils cultivated with yellow passion fruit
}

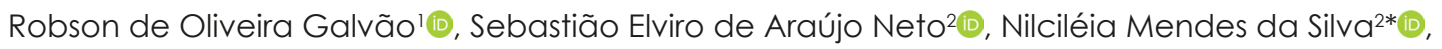

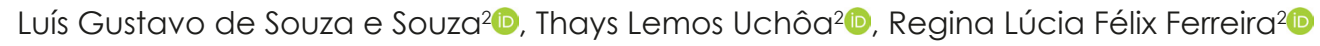

\author{
'National Supply Company, Rio Branco, Brazil \\ ${ }^{2}$ Federal University of Acre, Rio Branco, Brazil \\ *Corresponding author, e-mail: nilcileia-ac@hotmail.com
}

\begin{abstract}
This research aimed to evaluate the effect of doses of organic compost on the yield and economic profitability of organic yellow passion fruit grown in sandy-loam and clay-loam soils. Two experiments were installed in the field, in different soil types and municipalities in the state of Acre. The experimental design was in randomized blocks with five treatments, four replications, and four plants per experimental unit. The treatments consisted of adding the compost as a replacement for $1 / 3$ of the volume of cylindrical planting holes with $40 \mathrm{~cm}, 80 \mathrm{~cm}$, $120 \mathrm{~cm}, 160 \mathrm{~cm}$, and $200 \mathrm{~cm}$, corresponding to the addition of 6.3;25.1; 56.5; 100.4, and 156.9 liters per planting hole, respectively. The mean fruit mass and the yield of the yellow passion fruit were higher in sandy-loam soil. The total revenue was $R \$ 4,311.6 \mathrm{ha}^{-1}$ in the clayey soil and $R \$ 5,841.9 \mathrm{ha}^{-1}$ in the sandy soil. The total cost was higher in the clayey soil than in sandy soil. Both soils responded in quadratic function with an increase in the cost as the volume of organic compost was increased, ranging from $R \$ 12,736.00$ ha $^{-1}$ with 6.3 liters of compost per hole up to $R \$ 26,249.63 \mathrm{ha}^{-1}$ with 156.9 liters of compost per hole. Net income was negative for all compost volumes in both types of soil, responding linearly, with a reduction in revenue of $R \$ 80.82 \mathrm{ha}^{-1}$ with the addition of each liter of compost in the pit due to the low yield caused by period long drought.
\end{abstract}

Keywords: Amazonian soils, economic analysis, organic crops, Passiflora edulis Sims

\section{Introduction}

Passion fruit growing is an expanding activity since this crop offers quick economic return and welldistributed income throughout the year (Silva et al., 2020), turning Brazil into the largest producer of yellow passion fruit in the world (Passiflora edullis Sims). However, the potential of the crop is still little explored, and its yield is considered low (13.3 $\mathrm{kg} \mathrm{ha}^{-1}$ ) (IBGE, 2017), making it necessary to perform new studies in order to overcome technological bottlenecks, especially those related to fertilization.

Ecological agriculture is a food production alternative to ensure food sovereignty and higher competitivity (Araújo Neto \& Ferreira, 2019), besides the fact that the fruits produced in an organic system present superior physicochemical and nutritional properties related to the content of vitamins, phenolics, and antioxidants when compared to the conventional system
(Mditshwa et al., 2017).

In the state of Acre, several works developed with yellow passion fruit attest the positive aspects of organic agriculture, either in no-till systems with small planting rows (Araújo Neto et al., 2008), intercropped with pineapple, maize, cassava, and green manure (Araújo Neto et al., 2014), in coexistence with the stem borer (Rezende et al., 2017), grown using tall seedlings and with a long root system (Silva et al., 2019; Silva et al., 2020), or using mulch during the drought period in the region (Uchôa et al., 2018), contributing to the development of this production system.

However, in nearly a third of the soils of Acre, there is a predominance of high activity and permanent charge clays, with high expansion and contraction capacity, resulting in relevant physical impediments to the practice of agriculture (Wadt, 2002). This characteristic is undesirable since it affects the physical conditions of the 
soil, such as density, porosity, aeration, water retention, and infiltration capacity (Santos et al., 2013), causing direct damage through the disruption of roots during the drought period, requiring the adoption of appropriate care and management practices.

In this context, the use of organic compost constitutes an alternative to increasing the production, yield, and economic profitability of the crop since, besides macro and micronutrients, the organic matter acts by improving the physical, chemical, and biological conditions of the soil (Alves et al., 2011; Araújo Neto et al. 2014; Uchôa et al., 2018).

With the replacement of a form of technology, such as chemical fertilization for organic fertilization, the evaluation of the production cost and profitability of the activity constitutes an important instrument to attest to the economic viability of this work. Fertilization, as well as the method of implantation and conduction of the crop influence directly on the passion fruit production cost, being necessary to increase the yield, improve quality, and add value to the products (Araújo Neto et al., 2008) in order to reduce costs and increase the profitability of this crop.

Therefore, this study aimed to evaluate the effect of the organic compost as a conditioner of clay-loam and sandy-loam soils on the yield and economic profitability of passion fruit cultivation in an organic production system.

\section{Material and Methods}

The research was performed in the period from November 2014 to August 2016, through the simultaneous installation in the field of two experiments, in different soils of two municipalities of the state of Acre, although distant from each other by only 20 kilometers. The soil profiles, in the experiments, were classified according to Santos et al. (2013).

The first experiment was conducted in the municipality of Rio Branco/AC, in a Plinthic Allitic YELLOW ARGISOL with sandy-loam texture, slightly wavy topography, without apparent erosion, and with moderate drainage, located at the Seridó Ecological Site, Highway AC 10, km 04, junction José Rui Lino, km 1.7, in the geographic coordinates of $09^{\circ} 53^{\prime} 16^{\prime \prime}$ 'S latitude and $67^{\circ} 49^{\prime} 11$ l' W longitude, with an elevation of $170 \mathrm{~m}$.

The second experiment was performed in the municipality of Porto Acre/AC, in a Dystrophic Plinthic RED-YELLOW ARGISOL with silt clay-loam texture, slightly wavy relief, non-apparent erosion, and imperfect drainage, located at the Humaitá Settlement Project, Highway AC 10, km 22, junction Flaviano Melo, km 7, in the geographic coordinates of $09^{\circ} 48^{\prime} 18^{\prime \prime} S$ latitude and
67039'11" W longitude.

Soil samples were collected (0-20 cm depth layer) and analyzed in the Laboratory of Soils of the Federal University of Acre for the determination of the soil chemical composition. The sandy-loam soil contained pH 5.1 in $\mathrm{H}_{2} \mathrm{O}$; $2.0 \mathrm{mg} \mathrm{dm}^{-3}$ of $\mathrm{P}$; in $\mathrm{mmol}_{\mathrm{c}} \mathrm{dm}^{-3}, 1.8$ of $\mathrm{K} ; 19$ of $\mathrm{Ca} ; 9$ of $\mathrm{Mg}_{\text {, }}$ 8 of $\mathrm{Al}, 64$ of $\mathrm{H}, 29.8$ of sum of bases, and $17 \mathrm{mg} \mathrm{dm}^{-3}$ of O.M. The clay-loam soil contained pH 5.1 in $\mathrm{H}_{2} \mathrm{O} ; 2.0 \mathrm{mg}$ $\mathrm{dm}^{-3}$ of $\mathrm{P}$; in $\mathrm{mmol}_{\mathrm{c}} \mathrm{dm}^{-3}, 1.2$ of $\mathrm{K} ; 27$ of $\mathrm{Ca} ; 11$ of $\mathrm{Mg}, 18$ of $\mathrm{Al}, 70$ of $\mathrm{H}, 39.2$ of sum of bases, and $27 \mathrm{mg} \mathrm{dm}^{-3}$ of O.M.

The climate is classified as hot and humid, Amtype (Köppen, 1918), in both experimental areas. The mean monthly values of temperature, air relative humidity, and rainfall during the conduction of the experiments were obtained from the meteorological database of the National Institute of Meteorology (Table 1) (Inmet, 2017).

Table 1. Climatological data from the meteorological database for teaching and research (INMET) during the conduction of the experiment. Rio Branco, AC.

\begin{tabular}{ccccccc}
\hline \multirow{3}{*}{ Month } & \multicolumn{3}{c}{2015} & \multicolumn{3}{c}{2016} \\
\cline { 2 - 7 } & Rainfall & Tmean & R.H (\%) & Rainfall & Tmean \\
& $(\mathrm{mm})$ & $\left({ }^{\circ} \mathrm{C}\right)$ & & $(\mathrm{mm})$ & $\left({ }^{\circ} \mathrm{C}\right)$ & R.H $(\%)$ \\
\hline January & 240.4 & 25.35 & 89.88 & 96.3 & 27.08 & 91.17 \\
February & 287.9 & 25.6 & 90.41 & 220.6 & 27.02 & 90.36 \\
March & 282.1 & 25.53 & 90.75 & 227.5 & 26.53 & 88.11 \\
April & 212.2 & 26.18 & 88.65 & 318.3 & 26.54 & 86.54 \\
May & 170.2 & 25.29 & 90.29 & 94.0 & 24.97 & 86.76 \\
June & 57.50 & 24.89 & 85.38 & 2.0 & 23.82 & 81.55 \\
July & 5.90 & 24.77 & 82.74 & 11.7 & 25.23 & 74.03 \\
August & 46.80 & 26.93 & 76.98 & 30.6 & 26.19 & 68.69 \\
September & 105.4 & 27.56 & 77.26 & 80.2 & 25.9 & 76.45 \\
October & 97.80 & 27.24 & 78.41 & 211.3 & 26.71 & 81.44 \\
November & 327.1 & 27.41 & 81.45 & 169.9 & 26.35 & 84.61 \\
December & 179.1 & 26.73 & 85.07 & 219.3 & 26.11 & 87.78 \\
\hline Tmean- Mean temperature; Prec.- Total rainfall; R.H-mean relative humidity. Source: Data from the \\
INMEI network, 2017.
\end{tabular}

The experimental design was in randomized blocks with five treatments and four replications. The treatments corresponded to the use of $6.3,25.1,56.5,100.4$, and 156.9 $\mathrm{L}$ of organic compost per planting hole $\left(1 / 3 \mathrm{~V}^{-1}\right)$ mixed to the amount of soil required to fill planting holes with $40 \mathrm{~cm}$, $80 \mathrm{~cm}, 120 \mathrm{~cm}, 160 \mathrm{~cm}$, and $200 \mathrm{~cm}$ of diameter $\left(2 / 3 \mathrm{v} \mathrm{v}^{-1}\right)$, respectively.

The experimental unit (replication) was constituted by four plants, with a $3 \mathrm{~m}$ spacing between rows and $3 \mathrm{~m}$ between plants, occupying an area of 36 $\mathrm{m}^{2}$.

The organic compost used in the field, in the experiments, was acquired in 2014 from a company specialized in the production of organic fertilizers (Vitalys Cacoal Adubos Orgânicos LTDA) based in the municipality of Cacoal/RO. 
The organic compost was produced by the company based on wood sawdust, coffee straw, leaves, dry grass, rice husk, poultry litter, and bovine manure. A total of 12 tons of the product was acquired and transported with the aid of a dump truck from Cacoal/ $\mathrm{RO}$ to the places of the experiments. The compost was covered with a plastic tarp until its use at planting to avoid losses by weather effects and risks of contamination. The chemical and physicochemical characteristics of the commercial organic compost used in the experiments are presented in Table 2.

Table 2. Chemical and physicochemical characteristics of the organic compost produced in Cacoal/RO, wet base, used in the experiments for passion fruit cultivation.

\begin{tabular}{cccc}
\hline Characteristics & Values & Characteristics & Values \\
\hline Organic matter (\%) & 86.07 & Magnesium \%) & 0.11 \\
$\mathrm{C} / \mathrm{N}$ ratio & 18.39 & Sulfur (\%) & 0.24 \\
$\mathrm{pH}\left(\mathrm{CaCl}_{2}\right)$ & 6.28 & Iron $\left(\mathrm{mg} \mathrm{kg}^{-1}\right)$ & $20,696.24$ \\
$\mathrm{CEC} \mathrm{cmolc} \mathrm{dm}^{-3}$ & 21.8 & Manganese $\left(\mathrm{mg} \mathrm{kg}^{-1}\right)$ & 345.53 \\
Nitrogen $(\%)$ & 0.65 & Copper $\left(\mathrm{mg} \mathrm{kg}^{-1}\right)$ & 19.18 \\
Phophorus $\left(\%\right.$ of $\left.\mathrm{P}_{2} \mathrm{O}_{5}\right)$ & $2.8 \%$ & Zinc $\left(\mathrm{mg} \mathrm{kg}^{-1}\right)$ & 76.02 \\
Potassium $\left(\%\right.$ of $\left.\mathrm{K}_{2} \mathrm{O}\right)$ & $0.21 \%$ & Boron $\left(\mathrm{mg} \mathrm{kg}^{-1}\right)$ & 82.63 \\
Calcium $(\%)$ & 1.76 & & \\
CEC = Cation exchange capacity & &
\end{tabular}

In order to add the same amount of nutrients in all treatments, chemical fertilizers were applied as a source of $P$ (thermophosphate) and $K$ (potassium sulfate), in a similar amount to the treatment that received the highest volume of organic compost, with $2.8 \%$ of $\mathrm{P}_{2} \mathrm{O}_{5}$ and $0.21 \%$ of $\mathrm{K}_{2} \mathrm{O}$. Nitrogen $(\mathrm{N})$ was not corrected in the treatments since there are no chemical fertilizers with $\mathrm{N}$ sources with use allowed for organic agriculture.

Seedling production was made with seeds of an F2 synthetic passion fruit variety, originated from the Germplasm Bank of UFAC, composed of progenies 2, 20, $22,23,33,35$, and 37 from Viçosa/MG, State University of Northern Rio de Janeiro (Universidade Estadual do Norte Fluminense)/RJ, Brasiléia/AC, and Rio Branco/AC (Negreiros et al., 2008).

The passion fruit seedlings were produced in July 2014, at the Seridó Ecological Site, using plastic bags with capacity for 3.0 L containing a substrate based on soil, organic compost, ground palm stem, and ground vegetable charcoal at a 3:3:3:1 ratio, adding 1 $\mathrm{kg} \mathrm{m}^{-3}$ of dolomitic limestone and $1.5 \mathrm{~kg} \mathrm{~m}^{-3}$ of natural thermophosphate into the substrate (Silva et al., 2018).

The soil used in the substrate was collected from the upper layer of an anthropized area close to the plant nursery. The ouricuri palm stem (Attalea phalerata) was originated from a forest in the experimental area, being ground and sieved after the death of the structure. The organic compost was produced based on signalgrass piles exposed to the environment until their decomposition (on average, for six months).

Three passion fruit seeds were deposited per bag, at a $0.5 \mathrm{~cm}$ depth. Thinning was performed at 20 days after sowing, allowing only the most vigorous plant per bag.

The seedlings were kept in a plant nursery (covered with a $100 \mu$ transparent film), with microsprinkler irrigation twice a day in order to maintain the substrate within field capacity. Ninety days after sowing, the seedlings with approximately $120 \mathrm{~cm}$ height were taken for the installation of the two experiments in the field.

The preparation of the planting area was performed with the aid of a backpack motorized weeder to remove the spontaneous vegetation. After the natural drying of the straw, the yellow passion fruit seedlings were transplanted to cylindrical planting holes with different diameters, following the experimental scheme.

All planting holes were opened manually, with the aid of a hoe, at a $20 \mathrm{~cm}$ depth, with $1 / 3$ of the soil volume being replaced by the organic compost used in the different treatments.

However, although the incorporation of the organic compost was performed only in the soil volume equivalent to the width of the planting holes of the treatments, all holes were opened with a $200 \mathrm{~cm}$ diameter and $20 \mathrm{~cm}$ depth, thus avoiding the effect of soil preparation on the results of the experiments.

The yellow passion fruit seedlings were planted in November 2014 and conducted in a vertical trellis system with $2 \mathrm{~m}$ height, containing smooth wire $\mathrm{n}^{\circ} 12$ in a $3.0 \mathrm{mx}$ $3.0 \mathrm{~m}$ spacing, totaling 1,111 plants ha-1.

The cultural practices of the crop, such as plant training, pruning, weed management, and pest and disease contro006C, were performed throughout the conduction of the experiment (Rezende et al., 2017). Flower pollination was entomophile. For weed control, periodic cleanings and plant mulching were performed to avoid competition.

The data on the inputs, capital, and services were collected during the conduction of the experiments to serve as a basis for the economic analysis.

Were collected, from each experimental unit, approximately $350 \mathrm{~g}$ of adult passion fruit leaves (fully expanded and without apparent disease) and $300 \mathrm{~g}$ of soil, 21 months after the installation of the experiment in the field. These samples were subjected to drying in a forced-air oven at $65^{\circ} \mathrm{C}$ for three consecutive days to 
determine the moisture content of leaves and soil.

The fallen fruits and those still on the plants, with ripening stage from $40 \%$ of yellow rind, were harvested twice a week throughout the flowering period, being transported to the Laboratory of Phytotechnics of the Federal University of Acre - UFAC for the determination of the total number of fruits per plant, mean fruit mass, and yield of the passion fruit.

The following variables were evaluated: soil moisture content, obtained by the difference between the mass of the soil samples collected in the field and dried in a forced-air oven (\%); leaf moisture content, obtained by the difference between the wet and dry mass of leaves collected in the field and dried in a forcedair oven (\%); base diameter, determined with the aid of a digital pachymeter with $0.01 \mathrm{~mm}$ precision, at $2 \mathrm{~cm}$ from the base of the plant, 90 days after planting the seedlings in the field; total number of fruits per plant, determined by the quotient of the total number of fruits divided by the number of plants in each experimental unit; mean fruit mass, estimated by the quotient between the total mass of harvested fruits divided by the total number of fruits harvested in the same plot, expressed in grams per fruit; yield, estimated considering the product of the mean fruit mass, number of fruits per plant, final plant stand, and planting density, being extrapolated to 1 hectare and expressed in $\mathrm{tha}^{-1}$; and simplified economic analysis.

In order the perform the simplified economic analysis, the parameters of fixed investment, depreciation, profitability index, remuneration of family labor, profit margin, net income, benefit-cost ratio, and fixed, variable, and total costs were assessed using the methodology described by Reis (2007).

For the calculation of the depreciation (D), the linear method referring to each calculation was used, being calculated by the following equation, according to Reis (2007):

$$
D=\frac{\mathrm{Va}-\mathrm{Vr}}{\mathrm{Vu}} P
$$

In which:

$D$ - depreciation, $R \$$ /cultivation

Va-current resource value, $\mathrm{R} \$$

$\mathrm{Vr}$ - residual value (the retail or final value of the item after being used in a rational manner in the activity), $\mathrm{R} \$$

$\mathrm{Vu}$ - useful life (period in cycles in which the item is used in the activity)

$P$ - period considered, productive cycle

The depreciation of the stand structure (duration of 25 years, considering 2-year cultivation cycles and a residual value of $20 \%$ ), of the weed trimmer, and inputs (6,000 hours) was considered.

For that purpose, a maintenance cost of $1 \%$ for machinery and $0.80 \%$ for the inputs was used, with the inclusion of $100 \%$ in the variable cost, also considering the expenses with filters and lubricants, estimated in $10 \%$ of the fuel expenses.

Were added to the fixed and variable costs the opportunity cost $\left(6 \%\right.$ at $\left.\mathrm{a}^{-1}\right)$ and the land cost, which could be leased for another activity, in this case considering the raising of beef cattle, corresponding to $R \$ 15.00$ / month, equivalent to 0.92 Animal Unit (U.A) (1.5 heads per hectare), at a mean price of $R \$ 12.5 /$ head $/$ month.

Administration costs of $3 \%$ on the working capital were used. The costs of the inputs and other consumption materials, the values of equipment depreciation and service contracts, as well as the marketing price of the yellow passion fruits were assessed in the region in which the experiment took place.

For the determination of the manpower value, a daily pay methodology was considered based on the salary income of a rural worker on minimum wage, added by the collection of the following labor taxes and contributions: $12 \%$ of the National Institute of Social Insurance (INSS), 8\% of the Length of Service Guarantee Fund (FGTS), $13^{\text {th }}$ Salary, additional vacation pay, insurance, and education salary, representing $45.59 \%$ on the wage, divided by 260 working days per year, according to the methodology proposed by the National Supply Company (Conab, 2010).

The variable costs were determined by taking into account the costs with labor, inputs, marketing, and package.

The mean income (RMe) was obtained by considering the marketing of the organic passion fruit production at a price of $\mathrm{R} \$ 4.00 \mathrm{~kg}^{-1}$, which was the value paid to the producers at the time of the experiment.

The net income (profit) was calculated by the difference between the total value obtained with the sale of the production of 1.0 (um) hectare and the total mean cost per hectare for production and marketing, for a two-season productive cycle.

The profitability index (IR) was calculated based on the ratio between the gross income and the total operating cost (CopT).

The technical coefficients referring to the different treatments, implantation, and conduction of the crop were determined through the monitoring of the experiments. 
The statistical analysis of the data was performed first by the verification of the presence of outliers by Grubbs's test; the normality of errors was assessed by the ShapiroWilk test, and the homogeneity of variance was assessed by Bartlett's test. The analysis of variance was performed after the verification of the assumptions, and when the ' $F$ ' value indicated a difference between treatments $(p<0.05)$, the regression analysis was performed for the quantitative factor. For the qualitative factor, the means were compared by Tukey's test at $5 \%$ of probability.
The joint analysis of variance of the experiments was performed by observing the minimal variation between the highest and lowest mean square of the residuals of both experiments, for the verification of the effect of the evaluated factors.

\section{Results and Discussion}

The variables of mean fruit mass, yield, and total and net income were significantly superior $(p<0.05)$ in the sandy-loam soil compared to the clay-loam soil (Table 3).

Table 3. Mean fruit mass (MMF), yield (PROD), leaf moisture (L.M.), and total and net income of the yellow passion fruit grown in a sandy-loam soil at the Seridó Ecological Site, Rio Branco, AC, and in a clay-loam soil in the São Raimundo Colony, Porto Acre, AC, 2016.

\begin{tabular}{|c|c|c|c|c|c|}
\hline SOIL & $\begin{array}{c}\text { MMF } \\
\text { g fruit-1 }\end{array}$ & $\begin{array}{l}\text { PROD. } \\
\mathrm{Kg} \mathrm{ha}^{-1}\end{array}$ & $\begin{array}{c}\text { L. M. } \\
(\%)\end{array}$ & $\begin{array}{c}\text { Total income } \\
\mathrm{R} \$\end{array}$ & $\begin{array}{c}\text { Net income } \\
\mathrm{R} \$\end{array}$ \\
\hline Sandy-loam & $127.06 \mathrm{a}$ & $1460.44 \mathrm{a}$ & $74.63 \mathrm{~b}$ & $5,841.90 a$ & $-12,238.12 a$ \\
\hline Clay-loam & $95.01 \mathrm{~b}$ & $1077.91 \mathrm{~b}$ & $75.04 \mathrm{a}$ & $4,311.63 \mathrm{~b}$ & $-14,692.19 b$ \\
\hline $\mathrm{CV}(\%)$ & 21.49 & 42.53 & 0.58 & 42.53 & -16.46 \\
\hline $\mathrm{F}_{\text {block }}$ & $0.91^{\mathrm{ns}}$ & $0.343^{\text {ns }}$ & $0.286 \mathrm{~ns}$ & 0.343 & $0.316^{\text {ns }}$ \\
\hline $\mathrm{F}_{\text {treatment }}$ & $3.577^{n s}$ & $6.7^{* *}$ & & $3.959 * *$ & $0.260^{\text {ns }}$ \\
\hline
\end{tabular}

These values for the mean fruit mass in the organic system are similar to other studies (Araújo Neto et al., 2008; Araújo Neto et al., 2009; Araújo Neto et al., 2014; Uchôa et al., 2018), being below the standard preferred in the country for table marketing, which is superior to 200 $g$ (Araújo et al., 2012), even if the fruits from plants grown in sandy-loam soil present a superior mass to the national value, which is $120 \mathrm{~g}$ (IBGE, 2017).

Uchôa et al. (2018) found a fruit mass 18\% higher in sandy-loam soil compared to the fruits produced in clay-loam soil. The same behavior was observed in this research and may have occurred due to the adsorption or lower mineralization of the organic compost applied at base fertilization, since, according to Walpola \& Arunakumara (2010), the decomposition of organic residues in soils with high clay content is slow.

The moisture content in the leaves was higher in the clay-loam soil than in the sandy-loam soil (Table 3). This result may have been influenced by the fact that the clayloam soil possesses $37 \%$ more organic matter, and also by the texture of the clayey soil, which, according to Peres et al. (2010), reduces the losses by evapotranspiration, maintaining the water available to the plant for a longer period.

The total income was $R \$ 4,311.6 \mathrm{ha}^{-1}$ in the clayloam soil and $R \$ 5,841.9 \mathrm{ha}^{-1}$ in the sandy-loam soil (Table 3). This income is below the predictability of passion fruit production, which can reach a total income of up to $R \$$ $44,218.00 \mathrm{ha}^{-1}$ in the organic production system (Araújo Neto et al., 2014).
The net income was negative for all volumes of organic compost used in both soil types (Table 3). This net income is not a direct result of the production costs, but rather of the total income, which was low as a consequence of the low yield of this experiment. The net income of passion fruit production depends on the price, production, and especially the yield (Araújo Neto et al., 2008; Hafle et al., 2010; Ripardo, 2014).

In organic fruit growing, the production cost of the passion fruit is lower than in conventional agriculture, which allows, even with a yield of $12,165.8 \mathrm{~kg} \mathrm{ha}^{-1}$ in two seasons (a yield below the national average), a net income of R\$1 1,501.44 hal $^{-1}$ (Araújo Neto et al., 2008), whereas in the conventional system a yield above $28.3 \mathrm{t} \mathrm{ha}^{-1}$ is necessary to cover the production costs (Furlaneto et al., 2011).

The passion fruit yield was also low since this variable has a direct relationship with the number of fruits produced per plant. The yield response was linear as a function of the doses of organic compost, with 208.04 $\mathrm{kg} \mathrm{ha}^{-1}$ of passion fruit per each liter of organic compost added to the planting hole, reaching a maximum yield of $1,540.69 \mathrm{~kg} \mathrm{ha}^{-1}$ with $156.9 \mathrm{~L}$ of compost per planting hole (Figure 1A).

The maximum yield obtained in this research $\left(1.54 \mathrm{tha}^{-1}\right)$ represented only $17 \%$ and $11 \%$ of the average yield registered for the state of Acre (8.41 tha-1) and Brazil (13.35 $\mathrm{kg} \mathrm{ha}^{-1}$ ), respectively (IBGE, 2017), being even lower when compared to the crop production potential in the organic system and without artificial pollination $\left(21\right.$ t ha $^{-1}$ ) (Araújo Neto et al., 2014); it is also much lower 
than in the conventional system, with irrigation, protected environment, and artificial pollination ( $\left.68 \mathrm{tha}^{-1}\right)$ (Carvalho et al., 2010). The yield, however, can vary significantly in

the organic system, from 2.9 † ha-1 $^{-1}$ (Araújo Neto et al., 2008) to 21.0 t ha-1 (Araújo Neto et al., 2014).

B
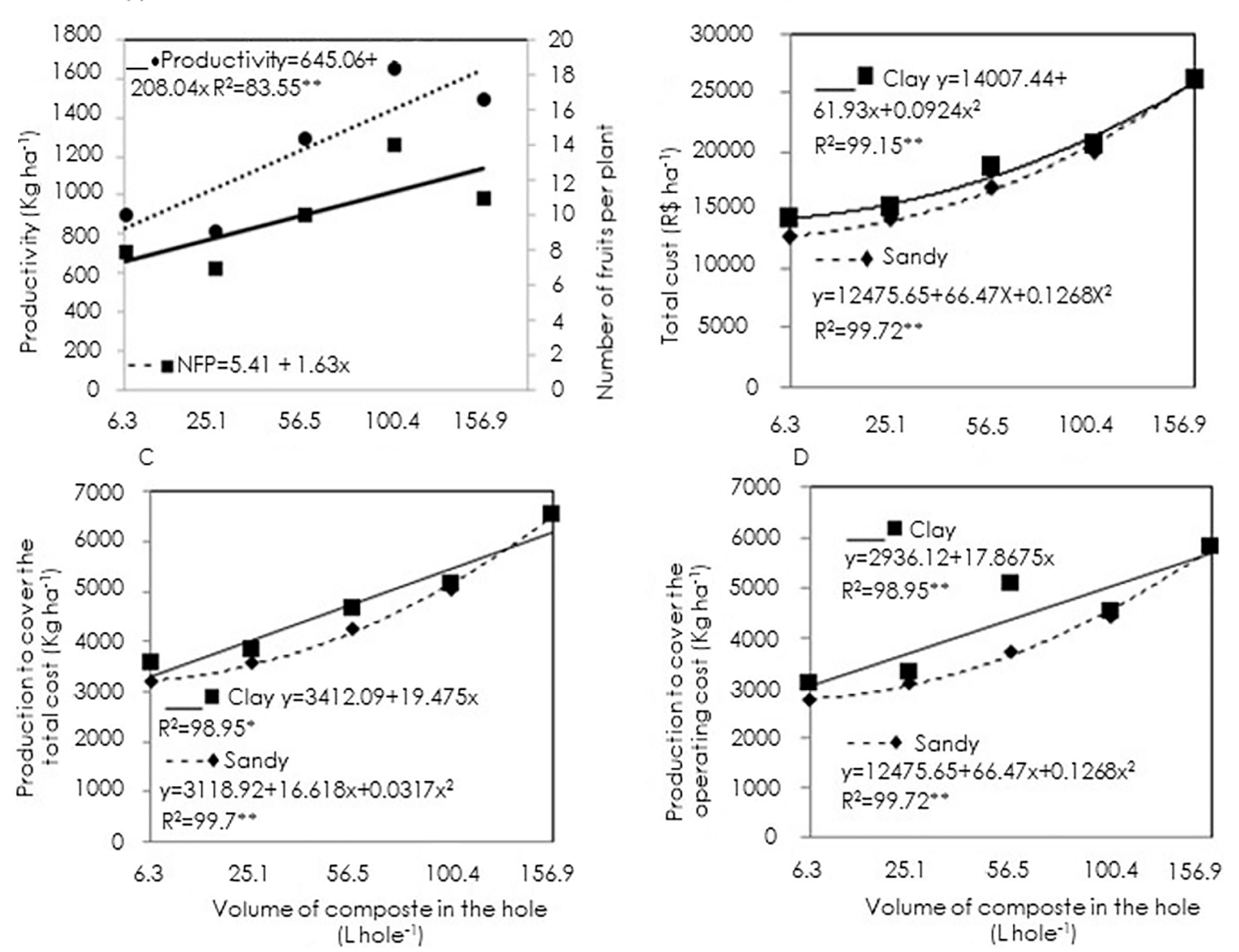

Figure 1. Productivity (yield) and number of fruits per plant (1A), total cost (1B), production to cover total cost (IC) and production to cover the operating cost (ID) in passion fruit cultivation depending on doses of organic compost.

The water deficit occurred at the beginning of the second growing season (main season) caused irreversible damage: the passion fruit plants did not bloom in this season, and the organic compost was not efficient in adsorbing water (Figure 1A).

In order to cover the total cost of this cultivation, the yield should be $6,536.09 \mathrm{~kg} \mathrm{ha}^{-1}$ with the maximum application of compost in the clay-loam soil, and $6,489.15 \mathrm{~kg} \mathrm{ha}^{-1}$ in the sandy-loam soil (Figure 1C).

The number of fruits per plant increased linearly, from 1.63 fruits per each liter of compost added to the planting hole, to a maximum of 12.11 fruits with 156.9 liters of compost (Figure 1A).

The number of fruits per plant is an important component for the yield and depends on two factors: flowering and pollination. In this manner, the use of natural pollination may have contributed to the low number of fruits per plant in this research since this pollination is naturally performed by carpenter bees (Xylocopa sp.) and fruit establishment can vary from 0 to $23 \%$, even in an ecological environment with primary vegetation and presence of pollinating bees (Yamamoto et al., 2010).

The low water availability at the beginning of the second season may have caused stress in the plants at a sufficient level to paralyze flowering in the subsequent period, which is why there was no flowering in the second season. According to Gomes et al. (2012), after a pronounced water deficit, the passion fruit plant does not return to its normal physiological condition, changing its normal photosynthetic activities, with possible damage in the receptor of electrons in the PSI photosystem. The water need during flowering should be, at least, $5,88 \mathrm{~mm}$ day $^{-1}$ (Freire et al., 2011).

Some studies report changes in photosynthetic activity in response to water deficit (Muller et al., 2011; Souza et al., 2018; Redillas et al., 2011; Waseem et al., 2011). These results evidence the main reason by which the plants did not resume growth and, therefore, presented affected flowering and yield.

According to Chavarria et al. (2015), a prolonged 
water deficit damages the vegetative growth due to the limitation of the development of the root system.

There was no interaction between the factors (soil $x$ fertilization) on most variables, except for the total cost, production for operating coverage, and production for total coverage (Figure 1B, 1C, and 1D).

The total cost was higher in the clay-loam soil compared to the sandy-loam soil (Figure 1B). In both soil types, the cost increase is represented by a quadratic function as the volume of organic compost was increased, varying from $R \$ 12,736.00 \mathrm{ha}^{-1}$ with 6.3 liters of compost per hole to $R \$ 26,249.63 \mathrm{ha}^{-1}$ with 156.9 liters of compost per hole (Figure 1B).

These costs increased with the higher volume of compost used and the manpower required to distribute and incorporate the fertilizer, although no elevation was registered in the fixed costs. The acquisition of inputs and manpower, in the intensive management of this crop, represents the highest costs (Hafle et al., 2010; Furlaneto et al., 2014). Therefore, there is a need to increment the yield in order to reduce the mean costs and increase economic profitability.

In the organic system, the production cost is low due to the absence of chemical fertilizers, which are replaced for green and organic fertilization and alternative pesticides, with lower prices (Araújo Neto et al., 2008).

The production for total coverage increased linearly in the clay-loam soil, $\mathrm{R} \$ 19.47 \mathrm{ha}^{-1}$, for the addition of each liter of compost, from $3,219.76 \mathrm{~kg} \mathrm{ha}^{-1}$ until the maximum limit of $6,536.09 \mathrm{~kg} \mathrm{ha}^{-1}$, and responded in a quadratic function with the increase in production from $3,528.94 \mathrm{~kg} \mathrm{ha}^{-1}$ up to the maximum limit of $6,489.15 \mathrm{~kg}$ $\mathrm{ha}^{-1}$ for the sandy-loam soil (Figure 1C).

Unlike some passion fruit growing systems that require 28.3 t ha ${ }^{-1}$ to cover the production costs (Furlaneto et al., 2011), in fruit farming it is possible to easily achieve this yield for being below the average of the state of Acre, $8.41+\mathrm{ha}^{-1}$, of the national average, $13.35+\mathrm{ha}^{-1}$ (IBGE, 2017), and well below the potential of this crop, which is 68 t ha $^{-1}$ (Carvalho et al., 2010). In organic fruit growing, with lower input consumption, only $2.8 \mathrm{tha}^{-1}$ is demanded to cover the production costs, obtaining profit from this yield upwards (Araújo Neto et al., 2008).

The production for operation coverage increased linearly in the clay-loam soil, being equivalent to 17.87 $\mathrm{kg} \mathrm{ha}^{-1}$ for the addition of each liter of compost, with a minimum yield of $2,778.2 \mathrm{~kg} \mathrm{ha}^{-1} \mathrm{up}$ to the maximum limit of $6,489.16 \mathrm{~kg} \mathrm{ha}^{-1}$; for the sandy-loam soil, it responded in a quadratic function with the increase in production from $3,043.32 \mathrm{~kg} \mathrm{ha}^{-1}$ up to the maximum limit of 5,759.14 $\mathrm{kg} \mathrm{ha}^{-1}$ (Figure 1D).

If it is not possible to cover the total cost, the yield to cover the operational costs can maintain activity in the short term, allowing capital recovery in the following growing seasons. In this case, with a low-yield estimation due to biotic and/or abiotic factors, the elimination of planting and the production of seedlings for a new planting may constitute an economically viable alternative, such as in regions with virus epidemics (Furlaneto et al., 2011) and, in this case, due to a prolonged water stress period.

\section{Conclusions}

The greater is the amount of organic compost used, the higher is the number of fruits per plant and the yield.

The organic compost up to 156 liters per planting hole does not retain enough soil moisture to keep the pants fructifying in a prolonged drought period.

The mean fruit mass and the yield of the organic yellow passion fruit are superior in sandy-loam soils.

The economic profitability of yellow passion fruit growing with the organic compost is higher in the sandyloam soil than in the clay-loam soil, in organic growing.

\section{References}

Alves, T.S., Campos, L.L., Elias Neto, N., Matsuoka, M., Loureiro, M.F. 2011. Biomassa e atividade microbiana de solo sob vegetação nativa e diferentes sistemas de manejos. Acta Scientiarum. Agronomy 33: 341-347.

Araújo, H.F., Costa, R.N.T., Crisóstomo, J.R., Saunders, L.C.U., Moreira, O.C., Macedo, A.B.M. 2012. Produtividade e análise de indicadores técnicos do maracujazeiroamarelo irrigado em diferentes horários. Revista Brasileira de Engenharia Agrícola e Ambiental 16: 159-164.

Araújo Neto, S.E., Campos, P.A., Tavella, L.B., Solino, A.J.S., Silva, I.F. 2014. Organic polyculture of passion fruit, pineapple, corn and cassava: the influence of green manure and distance between espaliers. Ciência e Agrotecnologia 38: 247-255.

Araújo Neto, S.E., Ferreira, R.L.F. 2019. Agricultura ecológica tropical. Araújo Neto, S.E., Rio Branco, Brazil. $169 \mathrm{p.}$

Araújo Neto, S.E., Ferreira, R.L.F., Pontes, F.S.T., Negreiros, J.R.S. 2008. Rentabilidade econômica do maracujazeiroamarelo plantado em covas e em plantio direto sob manejo orgânico. Revista Brasileira de Fruticultura 30: 940945.

Araújo Neto, S.E., Souza, S.R., Saldanha, C.S., Fontinele, Y.R., Negreiros, J.R.S., Mendes, R., Azevedo, J.M.A, Oliveira, E.B.L. 2009. Produtividade e vigor do maracujazeiroamarelo plantado em covas e plantio direto sob manejo orgânico. Ciência Rural 39: 678-683. 
Carvalho, J.A., Koetz, M., Sousa, A.M.G., Souza, K.J. 2010. Desenvolvimento e produtividade do maracujazeiroamarelo irrigado sob diferentes lâminas de irrigação em ambiente protegido e natural. Engenharia Agrícola 30: 862-874. Chavarria, G., Durigon, M.R., Klein, V.A., Kleber, H. 2015. Restrição fotossintética de plantas de soja sob variação de disponibilidade hídrica. Ciência Rural 8: 13871393.

CONAB. Companhia Nacional de Abastecimento. 2010. Custos de produção agrícola: a metodologia da Conab. Conab, Brasília, Brazil. 58 p.

Freire, J.L.O., Cavalcante, L.F., Rebequi, A.M., Dias, T.J., Souto, A.G.L. 2011 . Necessidade hídrica do maracujazeiro amarelo cultivado sob estresse salino, biofertilização e cobertura do solo. Revista Caatinga 24: 82-91.

Furlaneto, F.P.B., Esperancini, M.S.T., Martins, A.N., Okamoto, F., Vidal, A.A., Bueno, O.C. 2014. Análise energética do novo sistema de produção de maracujá amarelo na região de Marília-SP. Ciência Rural 44: 235240.

Furlaneto, F.P.B., Martins, A.N., Esperancini, M.S.T., Vidal, A. A., Okamoto, F. 2011. Custo de produção do maracujá-amarelo (Passiflora edulis). Revista Brasileira de Fruticultura 33: 441-446.

Hafle, O.M., Ramos, J.D., Araújo Neto, S.E., Mendonça, V. 2010. Rentabilidade econômica do cultivo do maracujazeiro-amarelo sob diferentes podas de formação. Revista Brasileira de Fruticultura 4: 1082-1088.

Gomes, M.T.G., Luz, A.C., Santos, M.R., Batitucci, M.C.P., Silva, D.M., Falqueto, A.R. 2012. Drought tolerance of passion fruit plants assessed by the OJIP chlorophyll a fluorescence transiente. Scientia Horticulturae 142: 49-56.

IBGE. Instituto Brasileiro de Geografia e Estatística. 2017. http://www.sidra.ibge. gov.br/bda/tabela/listabl. asp? $c=1613 \& z=p \& o=28<$ Acesso em 01 Out. 2019>

INMET. Instituto Nacional de Meteorologia. 2017. http:// www.inmet.gov.br/portal/ index. php?r=bdmep/ bdmep<Acesso em 07 Fev. 2018>.

Koppen, W. 1918. Klassifikation der klimate nach temperatur, niederschlag und jahreslauf. Petermanns Geographische Mitteilungen 64: 193-203.

Mditshwa, A., Magwaza, L.S., Tesfay, S.Z., Mbili, N. 2017. Postharvest quality and composition of organically and conventionally produced fruits: A review. Scientia Horticulturae 216: 148-159.

Muller, B., Pantin, F., Genard, H., Turc, O., Freixes, S., Piques, H., Gibon, Y. 2011. Water deficits uncouple growth from photosynthesis, increase $\mathrm{C}$ content, and modify the relationships between $C$ and growth in sink organs. Journal of Experimental Botany 62: 1717-1729.

Negreiros, J.R.S., Araújo Neto, S.E., Álvares, V.S., Lima, V.A., Oliveira, T. K. de. 2008. Caracterização de frutos de progênies de meios-irmãos de maracujazeiro amarelo em Rio Branco - Acre. Revista Brasileira de Fruticultura 30: 431-437.
Reis, R.P. 2007. Fundamentos de economia aplicada. UFLA/FAEPE, Lavras, Brazil. 95 p.

Peres, J.G., Souza, C.F., Lavorenti, N.A. 2010. Avaliação dos efeitos da cobertura de palha de cana-de-açúcar na umidade e na perda de água do solo. Engenharia Agrícola 30: 875-886.

Redillas, M.C.F.R., Strasser, R.J., Jeong, J.S., Kim, Y.S., Kim, J.K. 2011. The use of JIP test to evaluate droughttolerance of transgenic rice overexpressing OsNAC10. Plant Biotechnoloy 5: 169-175.

Rezende, M.I.F.L., Araújo Neto, S.E. de, Lustosa, C., Hafle, O.M., Pinto, G.P. 2017. Grafting for the recovery of yellow passion fruit stem in organic system. Revista Brasileira de Fruticultura 39: e-745.

Ripardo, A.K.S. 2014. Avaliação de genótipos de maracujazeiro e viabilidade econômica da cv. Roxinho do Kênia para exportação. 74 f. (Tese de Doutorado) Universidade Estadual Paulista, Botucatu, Brazil.

Santos, H.G., Jacomine, P.K.T., Anjos, L.H.C., Oliveira, V.A., Lumbreras, J.F., Coelho, M.R., Almeida, J.A., Cunha, T.J.F., Oliveira, J.B. 2013. Sistema brasileiro de classificação de solos. Embrapa, Brasília, Brasil. 354 p.

Silva, N.M., Araújo Neto, S.E., Souza, L.G.S, Uchôa, T.L., Ferreira, R.L.F. 2019. Organic cultivation of yellow passion fruit using tall seedlings with long root systems. Comunicata Scientiae 10: 477-483.

Silva, N.M., Souza e Souza, L.G. de, Uchôa, T.L., Almeida, W.A., Araújo Neto, S.E., Ferreira, R. L. F. 2018. Qualidade de mudas de maracujazeiro amarelo produzidas com substratos alternativos. Agropecuária Científica do Semiárido 14: 96-102.

Silva, N.M., Souza e Souza, L.G. de; Uchôa, T.L.; Araújo Neto, S.E., Silva, S.O. 2020. Profitability of organic passion fruit production using tall seedlings and root system. Revista Caatinga 33: 342-348.

Souza, P.U., Lima, L.K.S., Soares, T.L., Jesus, O.N, Coelho Filho, M.A., Girardi, E.A. 2018. Biometric, physiological and anatomical responses of Passiflora spp. to controlled water deficit. Scientia Horticulturae 229: 77-90.

Uchôa, T.L., Araújo Neto, S.E. de, Selhorst, P.O., Rodrigues, M.J.S., Galvão, R.O. 2018. Yellow Passion fruit performance in organic crop under mulch. Revista Brasileira de Fruticultura 40: e-212.

Wadt, P.G.S. 2002. Manejo de solos ácidos do Estado do Acre. Embrapa Acre, Rio Branco, Brazil. 28 p.

Walpola, B.C., Arunakumara, K.K.I.U. 2010. Decomposition of gliricidia leaves: The effect of particle size of leaves and soil texture on carbon mineralization. Tropical Agricultural Research and Extension 13: 19-23.

Waseem, M., Ali, A., Tahir, M., Nadeem, M.A., Ayub, M., Tanveer, A., Ahmad, R., Hussain, M. 2011. Mechanism of drought tolerance in plant and it management through different methods. Continental Journal Agricultural Science 5: 10-25. 
Yamamoto, M., Barbosa, A.A.A., Oliveira, P.E.A.M. 2010. A polinização em cultivos agrícolas e a conservação das áreas naturais: o caso do maracujá-amarelo (Passiflora edulis F. flavicarpa Deneger). Oecologia Australis 14: 174192.

Conflict of Interest Statement: The authors declare that the research was conducted in the absence of any commercial or financial relationships that could be construed as a potential conflict of interest.

All the contents of this journal, except where otherwise noted, is licensed under a Creative Commons Attribution License attribuition-type BY. 